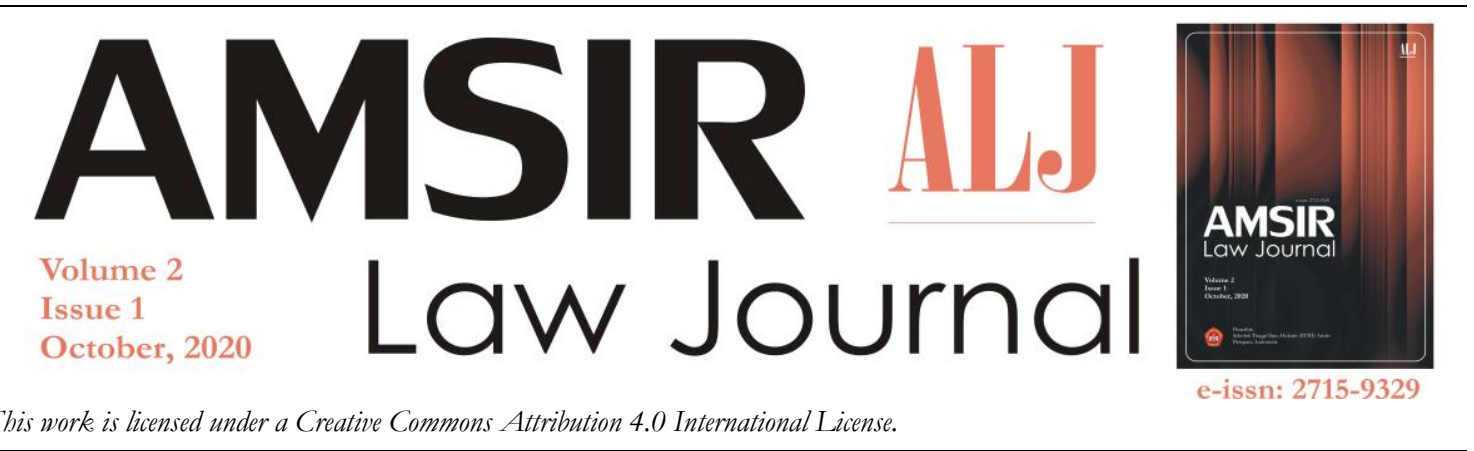

\title{
Pros-Cons of Implementing the Right to be Forgotten Rules in the ITE Law
}

\section{Saharuddin Saharuddin ${ }^{1}$}

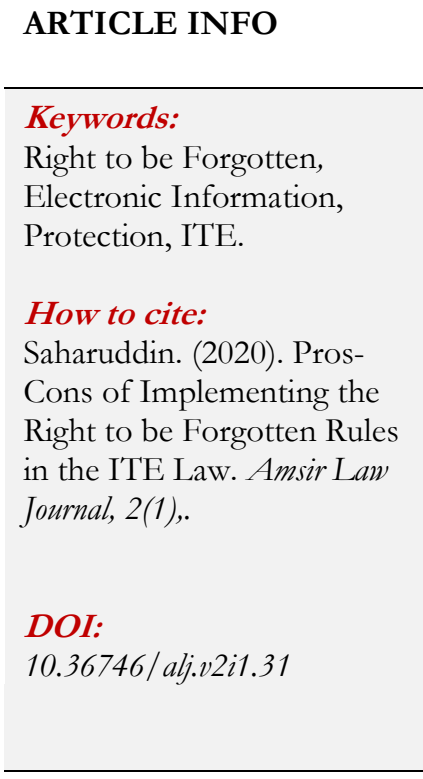

ABSTRACT

Article 26 paragraph (3) of Law number 19 the Year 2016 concerning Electronic Information and Transactions (The ITE Law) in Indonesian concerning the right to be forgotten. The contents of this article allow a person based on a court order to ask the electronic system administrator to delete irrelevant electronic information that is under their control. This provision conflicts with several other rights, which are also regulated in several laws. Like the location of the intersection right to be forgotten with the protection of personal data and public access to information.

\section{Introduction}

Article 26 paragraph (3) of Law Number 19 of 2016 concerning Amendments to Law Number 11 of 2008 concerning Information and Transactions of Electronic (The ITE Law of Indonesian) which regulates "the right to be forgotten" or the right for someone to have their information deleted on the internet. The essence of the article is that every electronic system operator is obliged to delete electronic information, if there is a request from the person concerned based on a court order, and every electronic system administrator is obliged to provide a mechanism for deleting electronic information that is no longer relevant.

Article 26 of the ITE law deserves to be criticized, imagine if we as citizens, a voter, and information on the track record of a political candidate be deleted because of a court ruling. Definitely, we want to know how the track record is concerned in many matters, for example, the matter of human rights (HAM), the environment, and corruption. With this information, the public can know the quality and integrity of those concerned. Besides, the provision of "the right to be forgotten" can also be abused by certain parties to delete

\footnotetext{
${ }_{1}$ STIH Amsir, Indonesia. Email: andi.saharuddin@yahoo.com
} 
information which is the public's right to know. Briefly, it is misused with information about a political candidate so that their bad track record cannot be detected and known to the public.

In Indonesia, freedom to obtain information is part of human rights, as regulated in the Law on Freedom of Information. Amendments to the ITE law are deemed inadequate, even though there is an intention to limit the distribution of information that is detrimental to the rights of others (reputation).

With the enactment of the new ITE law, the government must immediately formulate the provisions regarding "the right to be forgotten" with the explanation, and a more careful analysis based on the principles and norms of human rights which, according to Kuntjoro Purbopranoto, are rights that humans have according to their nature, which cannot be separated from their essence and are therefore sacred. ${ }^{2}$

The government must involve public participation in its formulation so that there is a transparent and participatory process. This intended so that the provisions regarding the right to be forgotten do not backfire on the public's right to know and the media's right to expression and are not used by certain parties to hide information with beneficial motivation himself (Personal Interest).

\section{Method}

This research aims to determine the pros and cons of implementing the right to be forgotten rules in the ITE law. The research method used in this research is a normative juridical approach, which is a method or procedure used to solve problems by examining secondary data ${ }^{3}$ by promoting analytical prescriptive descriptions. The normative juridical approach in this article is supported by various library materials such as literature in the form of books, journals, and articles in online media.

\section{Pros-Cons of Regulations related to the Right to be Forgotten in the ITE Law}

The first time, the right to be forgotten become a precedent in the European Court of Justice in 2014 regarding the case of Mario Costeja Gonzalez. This case began when Mario Costeja Gonzalez filed a complaint with Google Spain, which showed a link to information available in the digital archive of the La Vanguardia newspaper. This information contains property auction notifications in 1998 as well as the attachment procedure for social security debt recovery. In the end, this case won by the European Court, and Google Spain was obliged to delete it. This case received attention from the public. Since this case, the demand for the right to be forgotten has increased. Based on openness data from Google's official website, the number of links evaluated for deletion is 1.63 million.

In Indonesia, the right to be forgotten has been regulated in Article 26 paragraph (3) of Law Number 19 of 2016 concerning Amendments to Law Number 11 of 2008 concerning Information and Electronic Transactions (The ITE Law). This indicates that Indonesian citizens have the right to request the deletion of information or documents that are no longer relevant.

The rules in the ITE law regarding the right to be forgotten to accommodate the settings of the General Data Protection Regulation (GDPR). For example, Article 17 of the GDPR regarding specific requirements such as data that deleted must be irrelevant,

\footnotetext{
2 Purbopranoto, Kuntjoro. (1982). Hak-Hak Asasi Manusia dan Pancasila, Jakarta: Pradya Paramita, p. 19.

3 Soemitro, R.H., and Jurimetri. (1998). Metodologi Penelitian Hukum, Jakarta: Ghalia Indonesia, p. 10.
} 
inaccurate, or obtained by illegal means. GDPR itself is a data protection regulation that is part of European Union law. The right to be forgotten first regulated in law through the GDPR.

It's just that in the ITE law, there are no specific requirements as stipulated in Article 17 of the GDPR. These specific conditions are mandated by the ITE law to be further regulated in government regulations or ministerial regulations.

Even though Indonesia has arranged the right to be forgotten questions, however, the implementation process still cannot be done. This is because no government regulation or ministerial regulation is governing the mechanisms and procedures, even though this has been mandated by the ITE law. In 2018, the Ministry of Communication and Information Technology planned to issue a Ministerial Regulation regarding the right to be forgotten. However, until now there has been no sequel.

Considering cases that have occurred and the context of digital eternity today, the right to be forgotten is very needed. However, formulating policy about the right to be forgotten is not an easy problem. Therefore, Indonesia needs the right to be forgotten regulations that have limitations these restrictions are such as information that is useful for learning or the public interest that needs to be protected. So, information not only has the right to be deleted but also has the right to be protected, for example; information about a person with a criminal track record. Such as human rights actions, environmental crimes, and corruption should not be eliminated because they are in the public interest.

It's just that right to be forgotten has a conflict regarding free access to information. According to Bashori Muchsin, the general meaning of information refers to the availability of various kinds of materials, which are general knowledge or something that is considered as communication material. As a material for knowledge, information can be found in various forms and appearances, whether presented or not presented (published). As a communication material, information bridges between two parties or better as a subject or object of communication. ${ }^{4}$

Everyone certainly has the right to have free access to information on the internet. Apart from having opposition to freedom of information, the right to be forgiven also limits freedom of expression. Even though freedom of expression in Indonesia has been guaranteed by the 1945 Constitution of the Republic of Indonesia (UUD NRI 1945) in Article 28E paragraph (3) and Law number 9 of 1998 concerning the freedom to express opinions in public.

However, in this provision there are restrictions. The restrictions are on principles that must be the basis, one of which is the principle of balance between rights and obligations. Apart from having the right to express thoughts freely, there is an obligation to respect the rights of others to live in safety, order, and peace. In the right to be forgotten, safeguarding the peace of life of others from threats of invasion of privacy is the goal of establishing that right.

The right to be forgotten is still reaping many debates, but that doesn't mean it's unnecessary. Regulations that are limiting and prioritizing the public interest in the procedure for their elimination are prevention that can be done to freedom of opinion stay awake. This is what is applied in the GDPR because it contains certain conditions that must be fulfilled. The hope is that further regulation regarding the right to be forgotten in the ITE law in accommodating matters like this.

\footnotetext{
${ }^{4}$ Muchsin, Bashori. (2008). Analisis Tentang Hak Rakyat Atas Informasi Publik. Jakarta: Gramedia Pustaka Utama, p. 430.
} 


\section{Conclusion}

Revision of Law no.11 of 2008 concerning Information and Electronic Transactions (The ITE Law) through Law no. 19 of 2016 has included a new concept of the right to be forgotten. The impact of this regulation requires the obligation to carry out "Deletion of electronic information/electronic documents that are irrelevant" for electronic system administrators. The rules of the right to be forgotten in the ITE law cannot be implemented for various reasons. The article that was predicted by the DPR to protect this constitutional right to privacy turned out to be in vain.

Arrangements regarding the removal of personal information on the internet are still being debating. The right to be forgotten formula stipulated in Article 26 of the Information and Electronic Transaction (The ITE Law) is still vague. The difficulty in implementing these regulations lies in the intersection between the protection of personal data and public access to information.

\section{Acknowledgments}

I thank the editorial team of Amsir Law Jurnal for publishing me article in volume 2 (1), October 2020.

\section{References}

Books with an author:

Muchsin, Bashori. (2008). Analisis Tentang Hak Rakyat Atas Informasi Publik. Jakarta: Gramedia Pustaka Utama.

Purbopranoto, Kuntjoro. (1982). Hak-Hak Asasi Manusia dan Pancasila, Jakarta: Pradya Paramita.

Soemitro, R.H., and Jurimetri. (1998). Metodologi Penelitian Hukum, Jakarta: Ghalia Indonesia.

\section{Conflict of Interest Statement:}

The author declares that the research was conducted in the absence of any commercial or financial relationships that

could be construed as a potential conflict of interest.

Copyright $(0) 2020$ ALJ. All rightsreserved. 